Buryak V.G.,*

Buryak V.V., **

Drapak L.S., *

Buryak A.V.**

* Khmelnitsky Regional Institute of Postgrad-

uate Pedagogical Education,

** Khmelnitsky National University

Khmelnitsky, Ukraine

E-mail: viktorburyak1955@gmail.com

\section{AUTOCORRELATION FUNCTION OF MODEL OF IMAGE OF WORKING SURFACES OF COMPOSITE CUTTING PLATES}

UDC 621.9

DOI:10.31891/2079-1372-2019-91-1-48-51

The autocorrelation function of the model of the working surfaces of composite cutting plates is determined. The statistical processing of the microstructure of the working surfaces of the cutting plates on the basis of superhard grains with diffusion coatings has been carried out. According to the results of the research, histograms of the distribution of superhard grains on the working surfaces of the cutting plates were constructed. The efficiency of using the research results is proved, which allows to carry out the appropriate substantiation in the design of optical electronic devices for non-destructive quality control of composite cutting plates and in predicting the structural and energy state of the working surfaces of the plates and ensuring the guaranteed values of the period of stability of the tool. The results of research on the characteristics of the structural and energy state of the working surfaces of the cutting plates after sharpening give grounds to assert about the formation of a stable system of "grain-binder" materials. The obtained research results are the initial data when using the methodology of performance evaluation of cutting tools by analyzing the acoustic characteristics of the energy state of processing and instrumental materials using the differential equation of cause and effect relationship.

Key words: cutting machining, microstructure of working surfaces of tools, autocorrelation function, acoustic properties of materials, causal relationship, wear.

\title{
Introduction
}

Creation of a model of the image of working surfaces of composite cutting plates improves the possibility of unambiguous evaluation of the characteristics of the energy state of processing and instrumental materials by related parameters characterizing oscillation and wave processes at the stages of control outside the process and in the process of cutting (machining). Generalization of parameters is performed using the theory of causation [1-6]. To determine the characteristics of the structural and energy state of the working surfaces of composite cutting plates in the machine mode of modeling of rational technical parameters of the machining process, an autocorrelation function (ACF) is used. Thanks to the development of computer engineering, the numerical values of the components of ACF in the studies should be obtained by the method of optical recognition of objects using non-oriented pseudographs as a way of representing images of recognizable objects [7]. The use of research results allows to carry out the appropriate substantiation in the design of optical electronic devices for non-destructive quality control of composite cutting plates and in predicting the structural and energy state of the working surfaces of the plates and ensuring the guaranteed values of wear resistance of the tool.

\section{The purpose and task statement}

In order to use the differential equation of causation [1 - 6] an analysis of the characteristics of the energy state in the local contact of the processing and tool materials during the cutting process is performed. Composite tool materials are made in the form of plates. After sintering the plate is sharpened to remove defective layers, providing the specified dimensions of structural and geometric parameters. The process of sharpening is a complex technological process, which, along with its usefulness, can lead to the formation of various types of damage to the working surfaces, which in many cases reduces the reliability of the machining process. To analyze the characteristics of the structural and energy state of the working surfaces of composite cutting plates and the use of the results of research in the machine mode of modeling of rational technical parameters of the machining process, the autocorrelation function is determined.

\section{Presentation of research materials}

The statistical processing of the fifteen sections of typical photographs of super-hard materials (SHM) plates (Fig. 1, an increase of $500^{\mathrm{x}}$ and Figure 2, an increase of $125^{\mathrm{x}}$ ) is carried out. The number $n$ and density $\lambda_{\dot{K}^{\prime}}$ of the distribution of grains and their mathematical expectation $m_{i}$ on the surfaces of the plates are determined by the type of photographs depicted in Fig. 2, and the radius $r$ of superhard grains - by the type of photos 
Autocorrelation function of model of image of working surfaces of composite cutting plates

in Fig. 1 and Fig. 3 [8]. Numerical values in the studies are obtained by the method of optical recognition of objects using non-oriented pseudographs as a way of representing recognized images [7]. A generalized scheme of the process of optical recognition of objects is shown in Fig. 4.

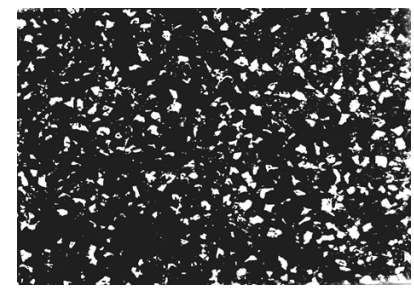

Fig. 1 - Typical photograph of the microstructure of the working surface of the cutting plate, $\mathbf{5 0 0}^{\mathrm{x}}$

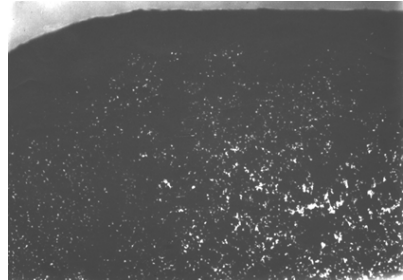

Fig. 2 - Typical photograph of the microstructure of the working surface of the cutting plate, $125^{\mathrm{x}}$

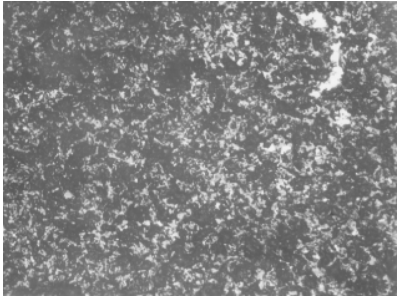

Fig. 3 - Microstructure of the working surface of the cutting plate on the basis of superhard grains with diffusion coatings, 500*

According to the results of the research, the histograms of the distribution of superhard grains on the working surfaces of the cutting plates (Fig. 5) were constructed. It was established that for the grain size of the

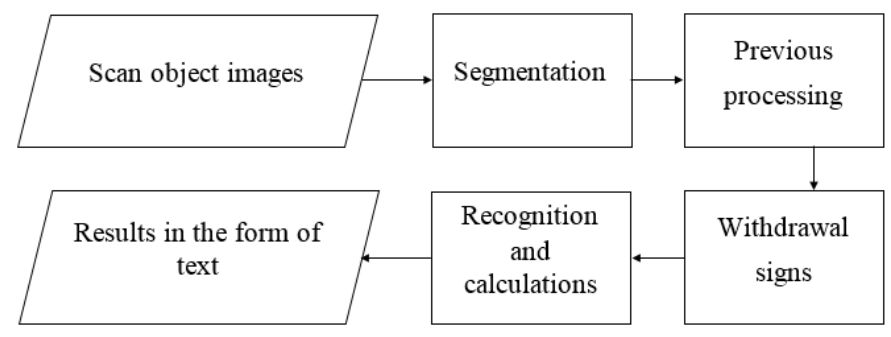

Fig. 4 - Generalized scheme of the process of optical recognition of objects superfine material 14/10 (according to the passport data on the diamond powder), the density of their distribution on the surface of the plate is higher (Fig. 5, a) than that of the plates with grains $10 / 7$ (Fig. 5, b) The probability of the size distribution of grain size in the range of $X=0,15, \ldots, 0,25$ microns $(\mathrm{mcm})$ is practically the same and has maximum values in this range. The verification of the received distribution laws was carried out according to Pearson's $\left(\chi^{2}\right)$ criterion. Jurisdictional scores obtained on the basis of $\chi^{2}$ the criteria for different plates satisfactorily coincide with the accepted hypotheses about the nature of the distribution.

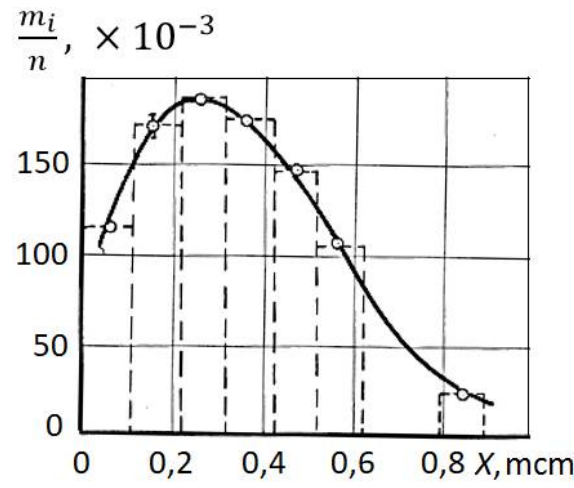

a

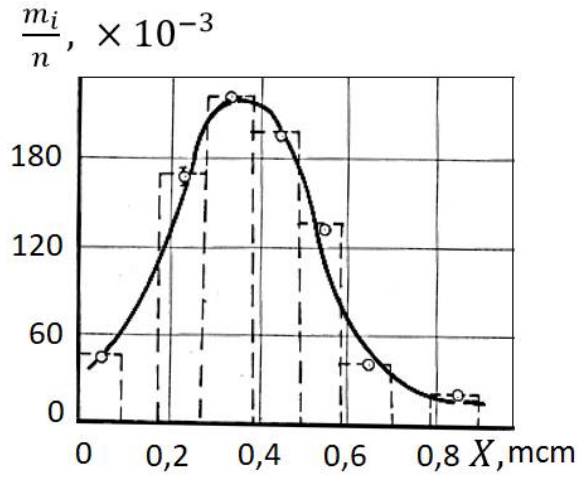

b

Fig. 5 - Histograms of the distribution of superhard grains on the working surfaces of the cutting plates by the numbers of grains: $a-14 / 10 ; b-10 / 7$

The autocorrelation function of the structural and energy state of the working surfaces of the cutting plates is determined using the model proposed in the publication [9], taking into account the technique [10] for the description of rough surfaces. In accordance with the method for determining the characteristics of the structural and energy state of the working surfaces of the cutting plates, the following assumptions are adopted: the shape of the grain from the superhard material is round; the illumination of the image within the contour of grains is constant and equal to one, and another field - to zero; the location of the centers of grains on the plane obeys the Poisson law. This allows you to write the ACF structural and energy state of the working surfaces of the cutting plates in the following form: 


$$
K_{\dot{K}}(\ell)=\left[\exp \left(-4 \pi \lambda_{\hat{K}} \int_{0}^{\infty} Z(r) r d r\right)\right] \times\left[\exp \left(4 \pi \lambda_{\dot{K}} \int_{0}^{\infty} \arccos \frac{\ell}{2 r} Z(r) r d r\right)-1\right] \text {, }
$$

where $Z(r)=1-\frac{1}{\sigma_{r} \sqrt{2 \pi}} \int_{0}^{r} \exp \left[-(r m r)^{2} \mid 2 \sigma_{r}^{2}\right] d r$;

$\lambda_{\dot{K}}-$ the grain density on the surface of the cutting plates within the field of vision;

$\ell$ - correlation interval;

$r$ - the radius of grain;

$m_{i}$ i $\sigma_{r}^{2}$-mathematical expectation and variance of the radius of grain.

Calculated data (1) of the ACF image of the working surfaces of the cutting plates show that, with the decrease in the grain size of superhard materials, the density of grain distribution on the working face decreases (Fig. 6). This fact is due to the technological process of sharpening the working surfaces of the plates. The individual small grains have a lower strength between the grain grip due to the reduced area of their contact with other grains and with the binder material. Therefore, the loss of small grains in comparison with large ones is more likely.

The use of the above results of research allows to carry out the appropriate substantiation in the design of optical electronic devices for non-destructive quality control of composite cutting plates and in predicting the structural and energy state of the working surfaces of the plates and ensuring the guaranteed values of the period of stability of the tool.

The results of research on the characteristics of the structural and energy state of the working surfaces

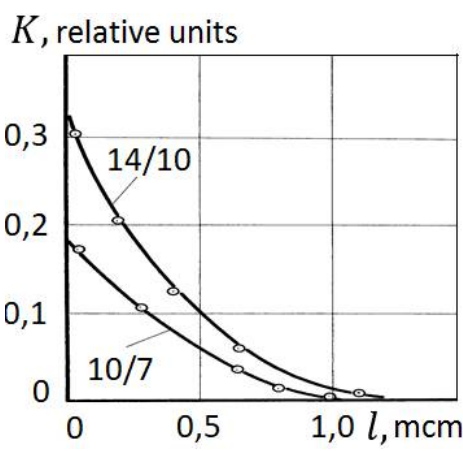

Fig. 6 - ACF model of the image of working surfaces of composite cutting plates of the cutting plates after sharpening give grounds to assert about the formation of a stable system of "grain-binder" materials. The solid core during the process of preparation and sintering of cutting plates under the influence of high values of pressure and temperature, as a rule, do not collapse and dissolve and retain their original sizes. However, during the sharpening of the working surfaces of the plates inevitably there is destruction (excising) of individual grains, rough isotropic surfaces with certain parameters are formed. In the process of cutting, due to the wear of the tool, the initial roughness parameters (formed during the sharpening of the working surfaces) change their values. It should be foreseen that due to the wear of the cutting layer, the values of standard roughness parameters vary $R a$ and $S m$ with varying intensity, depending on the working time of the tool. The disproportionate (periodic) change in the intensity of wear of the tool confirms the mechanism of destruction of the microstructure of the tool material due to the action of volatile and wave motions, which lead to the accumulation of stresses of tiredness, the formation and development of microcracks, etc. The deformation processes that take place in the tool material during cutting, cause internal friction in the microstructure of the individual volumes of grain, binder, and also, on the boundaries of contact of one grain with the other and grain with a dressing material. Important characteristics in the design of new instrumental materials, the margin of error determined when weighing the structural components (ingredients) for the production of serial plates is the specific value of the amount of grains and binder material per unit volume of the cutting layer. In order to perform a relative estimation of the internal friction activity, which determine the oscillatory and wave processes in the unit inequality of the rough work surfaces of the instrument, and the justification of the values of the parameters in the acoustic emission method of quality control of the composite cutting plates, an important characteristic is the number of grains placed in the microworld. This fact needs more detailed consideration when performing the analysis of the microstructural energy state of the instrumental material.

The obtained research results are the initial data when using the methodology of performance evaluation of cutting tools by analyzing the acoustic characteristics of the energy state of processing and instrumental materials with the use of the differential equation of cause and effect connection [1 - 6].

\section{Conclusions}

The autocorrelation function of the model of the working surfaces of composite cutting plates is determined. According to the results of the research, histograms of the distribution of superhard grains on the working surfaces of the cutting plates were constructed. It was established that for grains of superhard material 14/10 (ac- 
cording to passport data on diamond powder), the density of their distribution on the surface of the plate is higher than that of plates with grains 10/7. The probability of the size distribution of grain size in the range of $X=$ $0,15, \ldots, 0,25$ microns is practically the same and has maximum values in this range. Calculated data of ACF show that with a decrease in the grain size of superhard materials, the density of grain distribution on the working face decreases. This fact is due to the technological process of sharpening the working surfaces of the plates. The results of studies on the microstructure characteristics of the working surfaces of the cutting plates after sharpening give grounds to assert about the formation of a stable system of "grain-binder" materials. The solid core during the sintering of cutting plates under the influence of high pressure and temperature does not usually break down and dissolve and retain its original size. However, during the sharpening of the working surfaces of the plates inevitably there is destruction (excising) of individual grains, rough isotropic surfaces with certain parameters are formed.

The obtained research results are the initial data when using the methodology of performance evaluation of cutting tools by analyzing the acoustic characteristics of the energy state of processing and instrumental materials using the differential equation of cause and effect relationship.

\section{References}

1. Buryak V.G., Buryak A.V. Pokazniki energetichnogo stanu materialiv, shcho viznachayut' pracezdatnist' instrumentiv // Problemi tribologiï. - 2016. - № 2. - S. $54-57$.

2. Buryak A.V., Buryak V.G. Zv'yazok fiziko-mekhanichnih, teplofizichnih i akustichnih vlastivostej obrobnih i instrumental'nih materialiv u mekhanoobrobni // Problemi tribologiï.- 2016.- №2.- S.28-33.

3. Buryak A.V., Buryak V.G. Tekhnichna ocinka metodiki vikonannya analizu akustichnih harakteristik energetichnogo stanu instrumental'nogo materialu // Problemi tribologiï. - 2015. - № 3. - S. 71 - 77.

4. Buryak A.V., Buryak V.G. Naukovi osnovi do ocinki pracezdatnosti rizhuchih instrumentiv za analizom akustichnih harakteristik stanu obrobnogo i instrumental'nogo materialiv // Problemi tribologiï. - 2014. - № 4. - S. 23-30.

5. Buryak V.G., Buryak A.V. Zakonomirnosti zmini skladovih sili rizannya ta energetichnogo stanu obrobnogo i instrumental'nogo materiali v procesi obroblennya rizannyam // Problemi tribologiï. - 2017. - № 3 . - S. 25-29.

6. Buryak V.G., Buryak V.V., Drapak L.S., Buryak A.V. Analiz harakteristik mikrostrukturi poverhon' kompozicijnih rizhuchih plastin // Problemi tribologii. - 2018. - № 3. - S. 11-16.

7. Buryak V.G., Buryak A.V. Metod optichnogo rozpiznavannya tekstiv na osnovi neorientovanih psevdografiv // Vimiryuval'na ta obchislyuval'na tekhnika $\mathrm{v}$ tekhnologichnih procesah. -2018 . - № 2. S. $99-105$.

8. Ocenka rezhushchih svojstv instrumentov statisticheskimi metodami / Buryak V.G., Maslov V.P., Miheenko L.A. - Hmel'nickij, 1988. - 15s. - Rus. - Dep. v UkrNIINTI 24.01.89, №374 - Uk 89.

9. Koval' S.T., Miheenko L.A., Gromov K.S. Statisticheskie harakteristiki izobrazheniya poverhnosti polirovannyh metallov // Optiko-mekhanicheskaya promyshlennost'. - 1982. - №6. - S. 1-4.

10. O’Nejl EH. Vvedenie v statisticheskuyu optiku (Per. s angl.). - M.: Mir, 1966. -236 s.

Буряк В.Г., Буряк В.В., Драпак Л.С., Буряк А.В. Автокорреляционная функция модели изображения рабочих поверхностей композиционных режущих пластин.

Определена автокорреляционная функция модели изображения рабочих поверхностей композиционных режущих пластин. Проведена статистическая обработка микроструктуры рабочих поверхностей режущих пластин на основе сверхтвердых зерен с диффузионными покрытиями. По результатам проведенных исследований построены гистограммы распределения сверхтвердых зерен на рабочей поверхности режущих пластин. Доказана эффективность использования результатов исследований, что позволяет выполнять соответствующее обоснование при проектировании оптических электронных приборов для неразрушающего контроля качества композиционных режущих пластин и при прогнозировании структурно-энергетического состояния рабочих поверхностей пластин и обеспечения гарантированных значений периода стойкости инструмента. Результаты исследований характеристик структурно-энергетического состояния рабочих поверхностей режущих пластин после заточки дают основания утверждать о создании устойчивой системы "зерно-связующий" материалы. Полученные результаты исследований являются исходными данными при использовании методологии выполнения оценки работоспособности режущих инструментов по анализу акустических характеристик энергетического состояния, обрабатывающего и инструментального материалов с применением дифференциального уравнения причинно-следственной связи.

Ключевые слова: обработка резанием, микроструктура рабочих поверхностей инструментов, автокорреляционная функция, акустические свойства материалов, причинно-следственная связь, износ. 